\author{
Kozlov A.I. ${ }^{1)}$, Vershubsky G.G. ${ }^{1)}$, Butovskaya M.L. ${ }^{2,3,4)}$, Kozlova M.A. ${ }^{4)}$, Fedenok J.N. ${ }^{2)}$ \\ 1) Lomonosov Moscow State University, Anuchin Institute and Museum of Anthropology, \\ Mochovaya st., 11, Moscow, 125009, Russia \\ 2) Institute of Ethnology and Anthropology RAS, 119334 Leninsky prosp., 32a, Moscow, Russia \\ 3) Russian State University for Humanities, Miusskaya pl, 6, Moscow, 125993, Russia \\ 4) National Research University - Higher School of Economics, Miasnitskaya str., 20, 101990, Moscow, Russia
}

\title{
SECULAR TRENDS IN HEIGHT AND PELVIC SIZE OF OB UGRIANS (KHANTY AND MANSI)
}

\begin{abstract}
Introduction. Long term changes in the body height and female pelvic width of North-Western Siberia indigenous people - the Nothern Khanty and Sosva Mansi, were the subject matter of the study.

Materials and discussion. The indices under examination were averaged by decade to trace the changes from the 1860s to 1990s. Through the birth cohorts (BiCo) from the 1860s to 1930s, the stature of Ob Ugrians did not alter significantly. In successive generations, up to the 1990 s BiCo, there was an increase in body height. Males have became taller by $11.3 \mathrm{~cm}$, females - by $10.4 \mathrm{~cm}$ ( $p<0.0001$ for both sexes). Relative (to the height of the 1930s BiCo) growth amounted to $+7.18 \%$ and $+7.06 \%$ for males and females respectively. In females, body proportions have changed substantially. Alongside the increase in stature, pelvic width (d. cristarum) decreased from $28.9 \mathrm{~cm}$ in the $1930 \mathrm{~s}$ BiCo to $26.8 \mathrm{~cm}$ in the $1970 \mathrm{~s}$ BiCo. Hence, relative pelvic width narrowed by $2.1 \%$ (the factor of belonging to cohort is significant, $p<0.0001$ ).

Conclusion. The body height of Ob Ugrians changed unevenly. Shifts in somatic features followed after social transformations. Better quality of life over the period of individual growth and development affected the definitive body height. Thus, the long-term changes in somatic traits of the indigenous Khanty and Mansi people agree with the "quality of the environment" hypothesis of secular trends.
\end{abstract}

Keywords: long-term changes; stature; body proportions; d. cristarum; adults; Northern indigenous people; Siberia

\section{Introduction}

Long-term changes in the characteristics of people living in sub-extremal conditions are of interest to specialists in various fields of anthropology, medicine, and physiology. Meanwhile, studies on epochal changes in growth and development in Arctic indigenous populations are scanty [Shephard, Rode, 1996; Katzmarzyk, Leonard, 1998; Wigle et al., 2005; Kozlov et al., 2007; Kozlov et al., 2008], because these populations are difficult to reach and there is not enough data on their status in the past.

The focus group of our study was the indigenous people of the Khanty-Mansi Autonomous Okrug (KMAO), located in Western Siberia (Fig. 1). The Nothern Khanty and the Sosva Mansi inhabit northern areas of the Okrug, mainly between $62^{\circ}$ and $65^{\circ} 30 r^{\prime} \mathrm{N}$. The traditional activities of these people are hunting and fishery in the taiga zone, and reindeer breeding on the boundary of the taiga and tundra. Due to their linguistic, cultural, and anthropological similarity, the
Khanty and the Mansi are often united into a single group of Ob Ugrians [Funk, Sillanpaa, 1999]. The Ob Ugrians, together with the Nenets and the Selkups, comprise the indigenous (or native) population of the North of Western Siberia. Though the Khanty and the Mansi give their names to one of the largest northern regions of Russia, today they have become a typical ethnic minority: over $98 \%$ of people residing in their traditional territories are migrants from various places of the former Soviet Union. The Ob Ugrians differ from the migrant, mainly Slavic, population in both their language and cultural traditions. Currently, economic indicators (income, employment rate) in the indigenous groups of KMAO are much worse than in the region as a whole and nationwide [Kozlov, Lisitsyn, 2008].

Traditionally, Ob Ugrians led a semi-nomadic life. They spent winters in stationary settlements, while in the summertime families camped on their hunting grounds. Historical administrative (fiscal) documents of $17^{\text {th }}-19^{\text {th }}$ centuries contain records on the locations of the major stationary settlements of Khanty and Mansi 


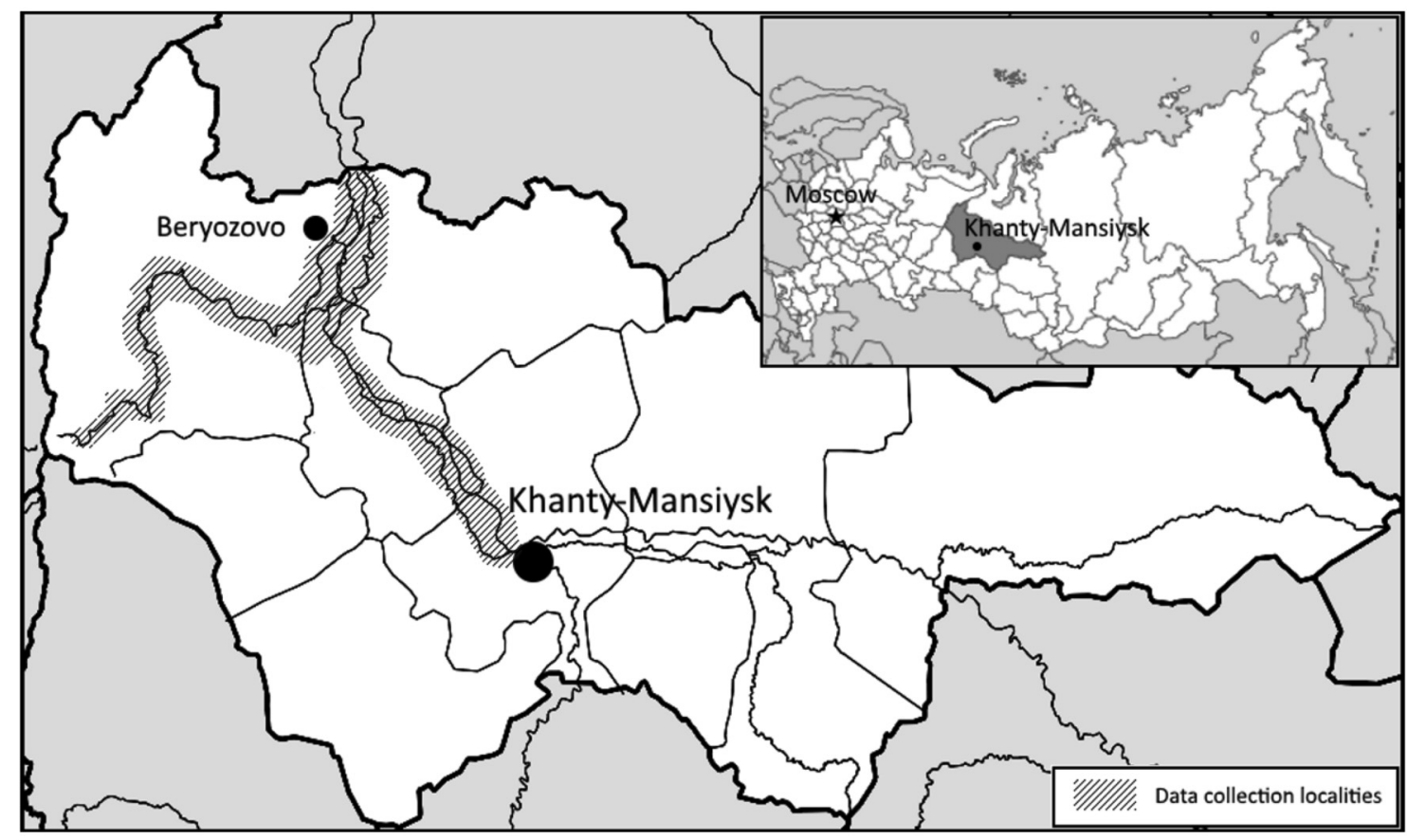

Figure 1. Geographic location of data collecting sites

Рисунок 1. Географическая локализация региона сбора данных

[Kabuzan, 1990]. According to $19^{\text {th }}$ century ethnographers [Sirelius, 1983], 20 th century anthropologists [Rudenko, 1914; Davydova, 1989], as well as our data, the locations of the major stationary settlements have not changed since. Thus, in the case of Ob Ugrians, it is possible to trace changes in growth and development in successive generations of population living in the same territory.

The aim of our study was to analyze the longterm changes in body height of males and females, and pelvis width and body proportions of females in Ob Ugrians, the indigenous people of North-Western Siberia.

\section{Materials and methods}

The subjects of our study were indigenous people residing in 21 rural settlements in KMAO (the areas where materials were collected are shown in Fig. 1). The subjects gave consent to scientific use of the data. In the course of our survey we gathered information on the subject's ancestry. Only those individuals whose both parents were ethnic Mansi or Khanty were included in the study group.

We examined 69 males aged $18-59$ years $(\mathrm{M} \pm \mathrm{SD}$ $33.3 \pm 11.9)$ and 223 females $17-63$ yo $(27.7 \pm 8.3)$ in $1988-90$, 59 males $18-63$ yo $(38.6 \pm 14.1)$ and 92 females 18-71 yo (30.3 \pm 14.3$)$ in 2009-11 (for more details see: [Kozlov et al., 2007; Butovskaya et al., 2016]). The individuals were assigned to birth cohorts (BiCo) spanning 10 years each.

Stature was measured by the authors themselves according to standard procedures [Frisancho 1990]. For the 210 women examined in 1988-1990 data on the width of the pelvis (distantia cristarum - DC) were also collected. The $\mathrm{DC}$ represented as a percentage of body height $(\mathrm{BH})\left[\mathrm{DC}^{*} 100 / \mathrm{BH}\right]$ was used as a measure of body proportions.

A comparison of our data with the data found in literature allowed us to track long-term changes in the body dimensions.

Our survey covered the same settlements where anthropometric examinations of indigenous people were conducted in 1909-10 and 1968-70. S. Rudenko published data on the age and height of 75 Mansi males collected in 1909-10 [Rudenko, 1914]. We assigned the subjects to birth cohorts in the same manner as in our own survey. G.Davydova [Davydova, 1989] did not provide individual age of her subjects (172 males and 165 females) examined in 1968-70. According to the average age of the group, we conventionally appointed it as the 1930s BiCo.

A preliminary analysis showed that the average height of Khanty and Mansi differs insignificantly. In the cohorts numerous enough to make statistical comparisons, differences did not reach the accepted level of significancy $(p=0.05)$. Thus we united these ethnic groups as Ob Ugrians. G.Davydova in her 
Table 1. Body dimensions of rural adult Ob Ugrians (Khanty-Mansi AO) by birth cohorts Таблица 1. Размеры тела сельских взрослых обских угров (Ханты-Мансийский АО) по когортам рождения

\begin{tabular}{|l|c|c|c|c|c|c|c|c|c|c|c|}
\hline & \multicolumn{4}{|c|}{ Males } & \multicolumn{9}{c|}{ Females } \\
\cline { 2 - 14 } Birth cohort & \multicolumn{3}{|c|}{$\begin{array}{c}\text { Body height } \\
(\mathrm{cm})\end{array}$} & \multicolumn{3}{c|}{$\begin{array}{c}\text { Body height } \\
(\mathrm{cm})\end{array}$} & \multicolumn{3}{c|}{$\begin{array}{c}\text { c. cristarum } \\
(\mathrm{cm})\end{array}$} & \multicolumn{2}{c|}{$\begin{array}{c}\text { D. cristarum } \\
(\% \text { to BH) }\end{array}$} \\
\cline { 2 - 14 } & $\mathrm{N}$ & $\mathrm{M}$ & SD & N & M & SD & N & M & SD & M & SD \\
\hline $1990-99$ & 7 & 168.6 & 6.71 & 32 & 157.8 & 5.95 & - & - & - & - & - \\
\hline $1980-89$ & 11 & 167.5 & 6.91 & 18 & 157.6 & 7.11 & - & - & - & - & - \\
\hline $1970-79$ & 9 & 161.1 & 6.62 & 37 & 152.0 & 7.30 & 26 & 26.8 & 1.52 & 17.8 & 0.98 \\
\hline $1960-69$ & 45 & 161.3 & 6.73 & 140 & 151.5 & 6.16 & 122 & 27.3 & 1.65 & 18.0 & 0.99 \\
\hline $1950-59$ & 26 & 162.0 & 6.34 & 57 & 151.2 & 4.19 & 51 & 28.5 & 2.00 & 18.9 & 1.25 \\
\hline $1940-49$ & 7 & 161.5 & 6.09 & 12 & 149.0 & 8.34 & 7 & 28.4 & 1.91 & 19.6 & 1.23 \\
\hline $1930-39^{1}$ & 172 & 157.3 & 5.12 & 165 & 147.5 & 5.12 & 4 & 28.9 & 2.32 & 19.7 & 1.05 \\
\hline $1880-89^{2}$ & 36 & 156.8 & 5.29 & - & - & - & - & - & - & - & - \\
\hline $1870-79^{2}$ & 22 & 156.2 & 4.93 & - & - & - & - & - & - & - & - \\
\hline $1860-69^{2}$ & 17 & 157.4 & 5.22 & - & - & - & - & - & - & - & - \\
\hline
\end{tabular}

Notes. 1 - data from [Davydova, 1989] and ours are combined. 2 - [Rudenko, 1914].

Примечания. 1 - объединены собственные данные и [Давыдова, 1989]. 2 - [Rudenko, 1914].

survey also found no difference in height between the Northern Khanty and Sosva Mansi [Davydova, 1989].

The Statistica 9.0 Program (StatSoft, US) was used for statistical analysis. When comparing groups by stature we used the Student's t-criterion. The Kruskal-Wallis ANOVA by ranks analysis was implemented to examine the differences in pelvic width. Post-hoc comparisons were then performed using Scheffe Test.

The study design was approved by the Ethics Committee of the Biological Faculty, Moscow State University, dated 26 March 2015.

\section{Results}

Descriptive statistics for somatic characteristics of rural Ob Ugrians by birth cohort are presented in Table 1.

\section{Secular trend in characteristics of males}

The birth cohorts in our study do not form a continuous series. There is no data for the decades from the 1890s to 1920s, but height in the 1930s BiCo statistically does not differ from height in all the 3 cohorts of the 19th century. Those born in the 1990s have become $11.3 \mathrm{~cm}$ taller $(168.6 \mathrm{~cm})$ than the 1930s BiCo $(157.3 \mathrm{~cm})$, i.e. there was an increase per decade of $1.6 \mathrm{~cm}$ on average.

However, the gain was uneven. There were two distinct increments (see Fig. 2). The first, less prominent, becomes apparent when comparing the 1930 s and 1950s BiCo (the number of subjects in 1940 s BiCo is very small and their stature does not differ statistically from that of the adjacent cohorts). The 1950s BiCo turned out to be, on average, $4.7 \mathrm{~cm}$ taller than the 1930s cohort $(p=0.007)$. The average increase per decade in these generations $(+2.35 \mathrm{~cm})$ is twice as high as the average for the century.

The second remarkable increase in stature of men (+6.4 cm: from 161.1 to $167.5 \mathrm{~cm}, \mathrm{p}=0.00008)$ occurred between the 1970s and 1980s BiCo (Fig. 2 ). The males born in the 1980 s and later are notably taller than those of the previous cohorts.

According to ANOVA, in the sequence of cohorts from 1930s to 1990s, the factor of belonging to cohort is highly significant $(p=0.0000)$.

\section{Secular trend in characteristics of females}

The difference in average stature between the female BiCo of the 1930s and 1990s was $10.4 \mathrm{~cm}$ (from 147.4 to $157.8 \mathrm{~cm}, p=0.0000$ ). That is, the average per decade increase was $1.49 \mathrm{~cm}$. The growth, like in males, contained two upswings (Fig. 3). The first occurred between the 1930s and 1950s BiCo, when average stature increased from 147.5 to $151.2 \mathrm{~cm}$ (i.e. by 1.85 per decade). Another rise separated the $1970 \mathrm{~s}$ and $1980 \mathrm{~s}$ BiCo. The change from 152 to $157.6 \mathrm{~cm}$ amounted to $5.6 \mathrm{~cm}$.

Pelvic width (Table 1) showed a sequential decrease in the array of cohorts from the 1930s to $1970 \mathrm{~s}(p=0.00002)$. Since at the same time stature has been increasing, the decline in relative (to height) pelvic width was even more prominent $(p=0.0000)$. 


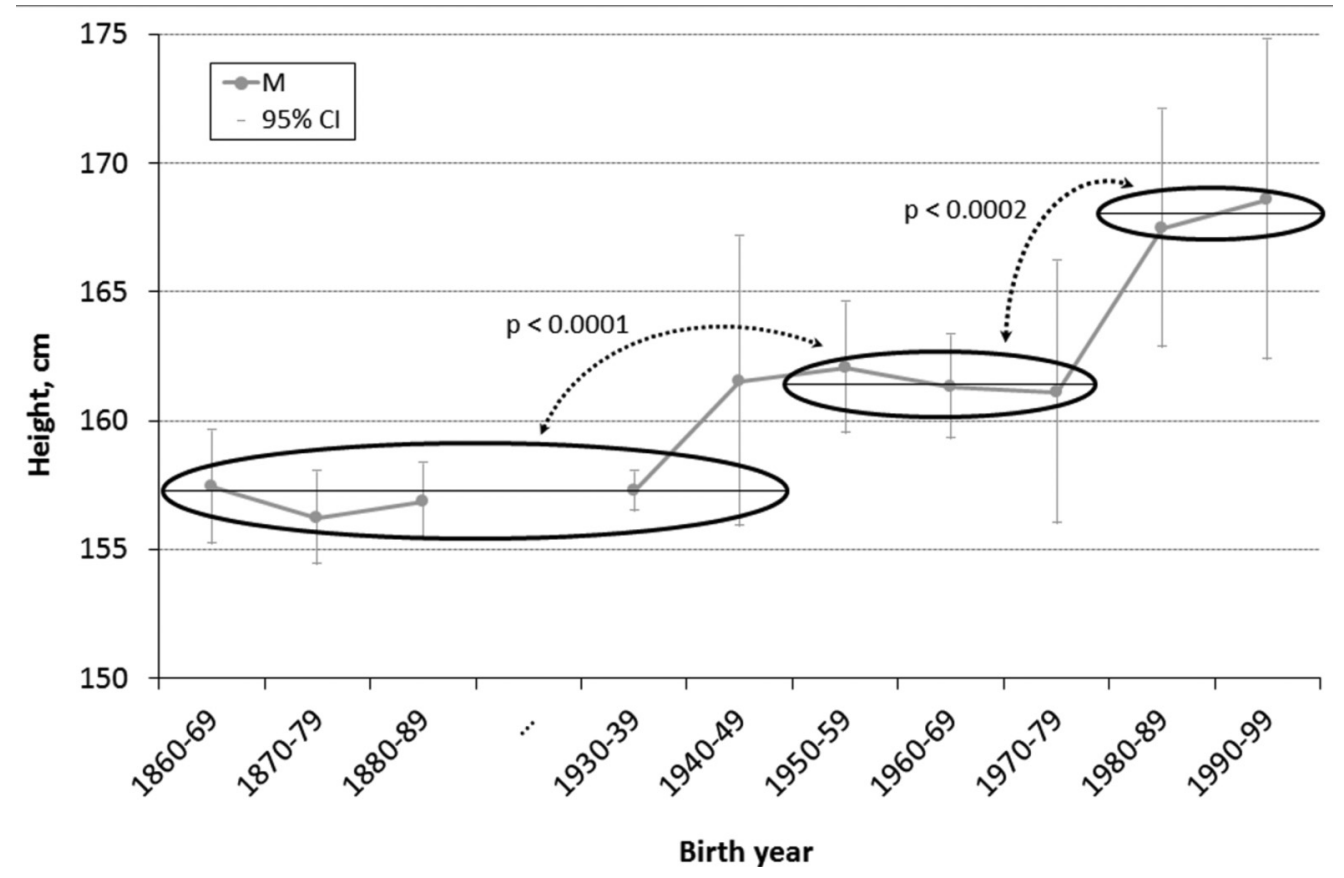

Figure 2. Ob Ugrians' body height by birth cohorts (males). The ovals depict the periods of relative stability. The significancies shown are pertinent to the period-average differences

Рисунок 2. Длина тела обских угров по когортам рождения (мужчины). Овалами выделены периоды относительной стабильности. Показанные уровни значимости относятся к разнице значений, средних за период

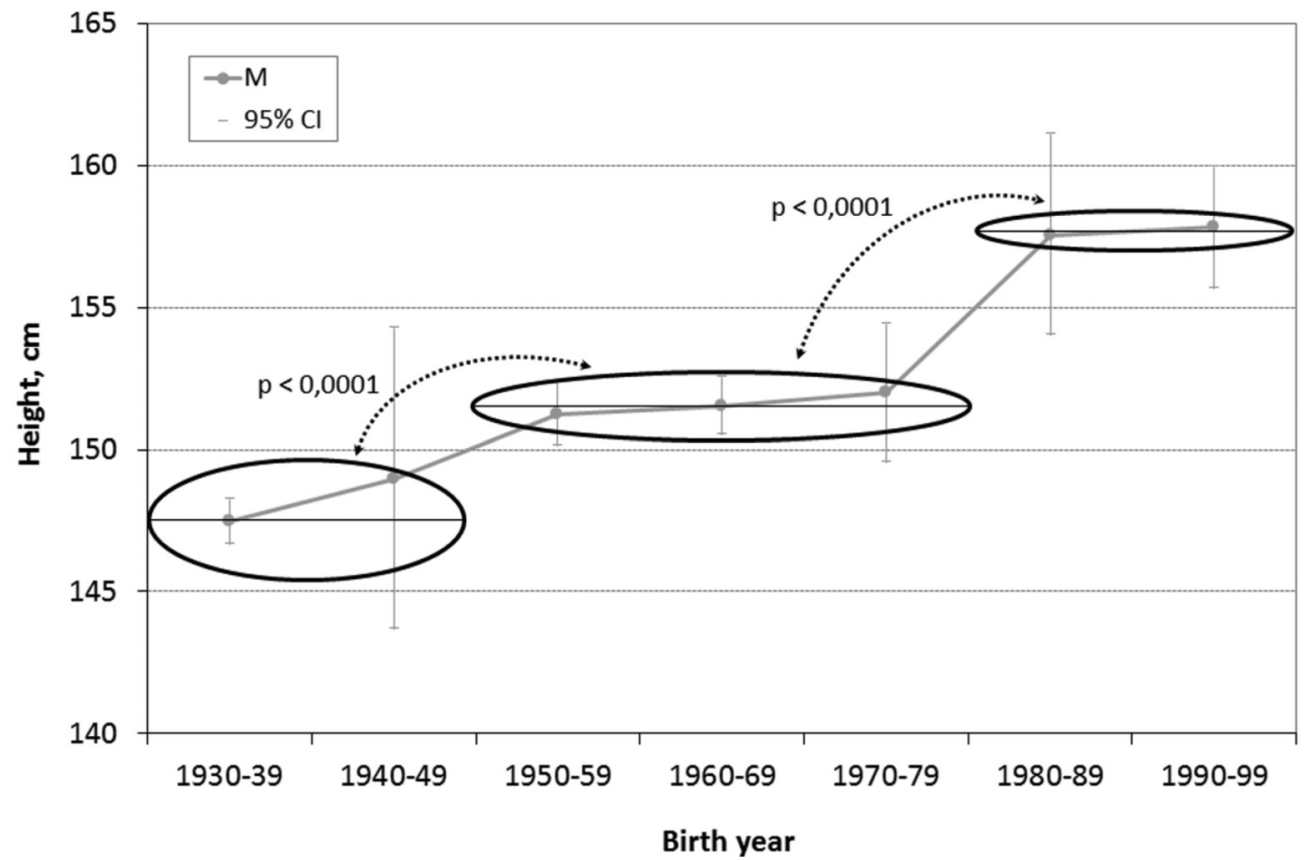

Figure 3. Ob Ugrians' body height by birth cohorts (females). The ovals depict the periods of relative stability. The significancies shown are pertinent to the period-average differences

Рисунок 3. Длина тела обских угров по когортам рождения (женщины). Овалами выделены периоды относительной стабильности. Показанные уровни значимости относятся к разнице значений, средних за период 
Table 2. Significance of difference in relative d.cristarum in pairs of birth cohorts

(by Scheffe Test) in Ob Ugrian females Таблица 2. Значимость различий относительных значений d.cristarum женщин обских угров при парном сравнении по когортам рождения (по тесту Шеффе)

\begin{tabular}{|l|c|c|c|c|}
\hline Birth cohort & $1930-39$ & $1940-49$ & $1950-59$ & $1960-69$ \\
\hline $1940-49$ & 0.999 & - & - & - \\
\hline $1950-59$ & 0.708 & 0.569 & - & - \\
\hline $1960-69$ & $\mathbf{0 . 0 5 8}$ & $\mathbf{0 . 0 0 7}$ & $\mathbf{0 . 0 0 0 2}$ & - \\
\hline $1970-79$ & $\mathbf{0 . 0 3 8}$ & $\mathbf{0 . 0 0 5}$ & $\mathbf{0 . 0 0 4}$ & 0.955 \\
\hline
\end{tabular}

The results of post-hoc paired comparisons of relative pelvic width in BiCo are shown in Table 2. The changes from the 1930s through 1950s BiCo were unsubstantial (the pair differences are statistically insignificant). Among those born in the 1960s and 1970 s, relative pelvic width was substantially smaller than in all the previous cohorts.

\section{Discussion}

Scholars of the 18th-19th centuries described the Ob Ugrians as one of the groups having the shortest stature among the population of the Russian Empire [Pallas, 1786; Nosilov, 1886]. Our research data agrees with this description. The height of Mansi males born in the 1860s was considerably lower than that of Russian males of the Cisurals $(-6.4 \mathrm{~cm})$ and in the 1930s BiCo the difference increased to -9.8 $\mathrm{cm}$ [Kozlov, Vershubsky, 2015]. Only the Kola Sami of the 1920s were similarly short-statured [Kozlov et al., 2008].

Through the BiCo from the 1860s to 1930s, the stature of Ob Ugrians did not change significantly, as the data on males show. In successive generations, up to the 1990s BiCo, there was an increase in body height. Males have became taller by $11.3 \mathrm{~cm}$, females - by $10.4 \mathrm{~cm}$ (Table 1; Fig. 2). Relative (to the height of the $1930 \mathrm{~s} \mathrm{BiCo}$ ) growth amounted to $+7.18 \%$ and $+7.06 \%$ for males and females respectively. The relative increase in the stature of $\mathrm{Ob}$ Ugrians exceeded that of rural Russian males, which, during the same time, was $+4.49 \%$ [Kozlov, Vershubsky, 2015]. Even though the Khanty and Mansi males remained smaller in stature than the rural Russians, the difference in absolute values decreased from 9.8 to $6.0 \mathrm{~cm}$ in the $1990 \mathrm{~s} \mathrm{BiCo}$.

In females, there were two intervals of rapid growth, which are noticeable when comparing the 1930 s with the $1950 \mathrm{~s}(+3.7 \mathrm{~cm})$, and the 1970 s with the $1980 \mathrm{~s}(+5.6 \mathrm{~cm})$ BiCo. In the cohorts from the 1950s through 1970s, body stature remained stable (Table 1, Fig. 3). The average height of rural Russian females in the BiCo from 1950s to 1980s also did not change much [Kozlov, Vershubsky, 2015]. Consequently the difference between Mansi and Russian females decreased from $8.1 \mathrm{~cm}$ in the $1960 \mathrm{~s} \mathrm{BiCo}$ to $1.7 \mathrm{~cm}$ in those born in the 1980s.

As we reported earlier, the Kola Sami exhibited similar rapid changes in the second half of the 20th century [Kozlov et al., 2008]. However, in this Arctic group, the maximal increase occured earlier, between the BiCo of the 1950s and 1960s. The increment in stature between the BiCo of the Sami females of the $1950 \mathrm{~s}$ and $1960 \mathrm{~s}$ amounted to $+7.8 \mathrm{~cm}$, while the $1970 \mathrm{~s}$ BiCo became only $+0.9 \mathrm{~cm}$ taller than the BiCo of the previous decade.

A possible explanation is that Soviet-style "Westernization" of the Kola Sami began in the late 1920 s (that is, earlier) and was imposed more persistently compared with other groups of indigenous people of the Russian North. By the end of 1930s, forced collectivization had already been completed on the Kola Peninsula. During the two postwar decades, the vast majority of the Sami were compulsorily relocated to four big settlements, and in $198944 \%$ of them resided in just one Lovozero population center [Lukyanchenko, 2002; Kozlov et al., 2008]. Thus, the Kola Sami of the 1960s BiCo can be regarded as already a post-traditional group, largely affected by demographic and social transformations (in diet, health care, living conditions, etc.) that could induce the observed physical changes.

Unlike the Sami, the Ob Ugrians remained an isolated group for a longer period of time, due to their vast, remote and difficult to reach territory. In the first decades of the 20th century, the Ob Ugrians still kept their specific features - language, beliefs, main elements of social and land-use practices [Sokolova, 1982]. The assimilation of the Ob Ugrians into the post-traditional world occurred in two phases. The first one involved active introduction of the Soviet lifestyle in the 1930s. There was a campaign for hygiene skills promotion. People got access to basic medical care, mainly provided by nurses and paramedics. The first wave of "modernisation" was followed by the first prominent increase in body height: $+4.7 \mathrm{~cm}$ in males, $+3.7 \mathrm{~cm}$ in females between the 1930s and 50s BiCo (Fig. 2, 3). At the same time, in the 1950 s, as medical care became more accessible and infant mortality declined, the average age of death among Mansi increased by more than 10 years (compared to the 1930s), reaching 27 years in females and 35 in males [Pivneva, 1999]. 
The cultural centers and paramedical stations established in the 1930s continued to operate during and after the Second World War. The next stage of drastic lifestyle changes followed after a substantial delay, in the 1950-60s. The main development of that time was a program of "consolidation", a mandatory relocation from traditional small hamlets into large settlements. There usually were post and local administration offices, a store, boarding school, paramedic station or small local hospital. Providing of public amenities was minimal: up to now there is often no street lights, centralized water and heating supply. The settlements, separated by tens and hundreds kilometers, have no road connections and are only reachable by air or river in the summer.

This obligatory, often enforced, relocation of the indigenous people had a number of adverse effects [Kozlov et al., 2007]. However, the program has helped to improve availability of modern health care services, enhance medical control over pregnancies and care for the newborn and children. Developments in the network of local hospitals ensured a growth in the number of hospital beds, doctors, and paramedical personnel [Kozlov, Lisitsyn, 2008]. All indigenous children were appointed to boarding schools with the full state-covered allowance for lodging, medical care and food, which was provided according to national regulatory standards [Kozlov, Lisitsyn, 2008]. As a result of these reforms, the average age of death among Mansi in the 1960s increased up to 44 years in males and 56 in females. These indicators, highest for the period 1930-2000, remained relatively stable for 20-25 years [Kozlov et al., 2007]. The changes in body stature followed. While in the 1950-1970s BiCo height did not vary much, those born in the 1980$90 \mathrm{~s}$, the descendants of the most "thriving" generation, showed a substantial gain of $+7.5 \mathrm{~cm}$ in males and $+5.8 \mathrm{~cm}$ in females (Fig. 2, 3). Concurrently, in the sequence of BiCo starting from the 1960s, body proportions showed a noticeable tendency to change: relative (to height) pelvic width in females has been decreasing (Tables 1, 2).

\section{Conclusion}

The long-term changes in somatic traits of the indigenous Khanty and Mansi people of Northern Western Siberia agree with the "quality of the environment" hypothesis of secular trends [Wolanski, 1985; Bogin, 1999].

Body height, when comparing the 1930 s and 1990s BiCo, 60 years apart, increased by $11.3 \mathrm{~cm}$ in males (from 157.3 to $168.6 \mathrm{~cm}$ ) and $10.4 \mathrm{~cm}$ in females (from 147.5 to $157.8 \mathrm{~cm}$ ). Body proportions changed substantially in females. Alongside the increase in stature, $d$. cristarum decreased from 28.9 $\mathrm{cm}$ in the 1930s BiCo to $26.8 \mathrm{~cm}$ in the $1970 \mathrm{~s} \mathrm{BiCo}$. Consequently, relative pelvic width narrowed by $2.1 \%$ (according to ANOVA, the factor of belonging to cohort is significant, $p=0.000000$ ). Similar changes were described in groups having a post-traditional and modern way of life [Kozlov, Vershubsky, 2015].

The body height of $\mathrm{Ob}$ Ugrians changed unevenly. Shifts in somatic features followed after social transformations. Better quality of life over the period of individual growth and development affected the definitive body height. Similar processes were described in other population groups of Russia (Mironov, 2012; Kozlov, Vershubsky, 2015].

\section{Limitations}

It is known that after the age of 30-40 body height begins to diminish with aging [Cline et al., 1989; Strickland, 1998]. J.D. Sorkin et al. [1999] described this decrease by a regression equation. However, this model was based on the data collected in The Baltimore Longitudinal Study of Aging, where subjects mainly were well educated, middle to upper-middle class white Americans. Our target population is very different by their Asian origin, health and nutritional status, level of physical activity etc. Hence, we infer, that the regression model of J.D. Sorkin et al. [1999] is not applicable to our data set. There is no data to build a credible equation for our study group. Therefore, the possible old-age-related changes in stature were not considered in our analysis.

\section{Acknowledgements}

The study was supported by RFBR grant \# 1809-00487.

The study was carried out at the Research Institute and Museum of Anthropology, Moscow State University, in the framework of the scientific research theme A16-116030210018-7 "Contemporary issues on human biological variability" (AK, GV), and at the Institute of Ethnology and Anthropology of the Russian Academy of Sciences in the framework of the scientific research theme N 01201370995 "Crosscultural and interdisciplinary studies" (MB)

The authors appreciate the help of Postnikova E.A. and Dronova D.A. in collecting data. 


\section{References}

Davydova G.M. Antropologiya mansi [Anthropology of Mansi]. Moscow, Institute of Ethnografy AN SSSR Publ., 1989. 128 p. (in Russ).

Kabuzan V.M. Narody Rossii v XVIII veke. Chislennost $i$ etnicheskiy sostav [Peoples of Russia in the $18^{\text {th }}$ century. Numbers and Ethnic Composition]. Moscow, Nauka Publ., 1990. 256 p. (in Russ).

Kozlov A.I., Lisitsyn D.V., Kozlova M.A., Bogoyavlenskij D.D., Borinskaya S.A. et al. Kolskiye saamy $v$ menyayushchemsya mire [Kola Sami in Changing World]. Moscow, Institut Nasledija Publ., 2008. 96 p. (in Russ).

Lukyanchenko T.V. Gosudarstvennaya politika i traditsionnaya kultura saamov: Problemy vozrozhdeniya [State Policy and the Traditional Culture of Sami: Matters of revival]. In: Rasy i Narody vyp. 28 [Races and Peoples, vol. 28]. Moscow, Nauka Publ., 2002, pp. 110-120. (in Russ)

Nosilov K.D. Antropologicheskiy ocherk vogulov [Anthropological discription of Voguls]. Proceedings of Anthropological branch of public society for Natural history, anthropology, and ethnography from December 4, 1881 trough 1886. 1886, pp. 528-539. (in Russ).

Pivneva E.A. Mansi: Populyatsionnaya struktura. etnodemograficheskiye protsessy (XVIII-XX vv.) [Mansi: The Structure of Population, Ethnodemographic Processes $\left(18^{\text {th }}-20^{\text {th }}\right.$ centuries]. Moscow, IEA RAN Publ., 1999. 306 p. (in Russ).

Rudenko S. Antropologicheskoye issledovaniye inorodtsev severozapadnoy Sibiri [Anthropological study of the indigenous people of Nort-West Siberia]. Proc. Imp. Acad. Sci. Series 8, Phys.-Math. Dept, 1914, 33 (3), pp. 1-125. (in Russ).

Sokolova Z.P. Sotsialnaya organizatsiya khantov i mansi v XVIII $X I X v v$. Problemy fratrii i roda [Social Organisation of Khanty and Mansi in $18^{\text {th }}-19^{\text {th }}$ centuries. Matters of Phratry and Clan]. Moscow, Nauka Publ., 1982. 324 p. (in Russ).

Butovskaya P.R., Lazebny O.E., Sukhodolskaya E.M., Vasiliev V.A. Dronova D.A. et al. Polymorphisms of two loci at the oxytocin receptor gene in populations of Africa, Asia and South Europe. BMC genetics, 2016, 17, pp..17. DOI: 10.1186/s12863-015-0323-8. Cline M.G., Meredith K.E., Boyer J.T., Burrows B. Decline of height with age in adults in a general population sample: estimating maximum height and distinguishing birth cohort effects from actual loss of stature with aging. Human Biology, 1989, 61 (3), pp. 415-425. Frisancho A.R. Anthropometric Standards for the Assessment of Growth and Nutritional Status. Ann Arbor, The University of Michigan Press, 1990. 189 p.
Funk D.A., Sillanpaa L. The Small Indigenous Nations of Northern Russia: A Guide for Researchers. Turku, Abo Academi University: Social Science Research Unit, Publication 29. 184 p.

Katzmarzyk P.T., Leonard W.R. Climatic influences on human body size and proportions: Ecological adaptations and secular trends. Am. J. Phys. Anthropol., 1998, 106 (4), pp 483-503.

Kozlov A., Vershubsky G., Kozlova M. Indigenous Peoples of Northern Russia: Anthropology and Health. Oulu, Intern. Assoc. Circumpolar Health Publ. Circumpolar Health Supplements, 1, 2007. 184 p.

Kozlov A., Lisitsyn D. Arctic Russia. In: Health Transitions in Arctic Populations. Ed. by T.Kue Young, P. Bjerregaard. Toronto, Buffalo, London, University of Toronto Press, 2008, pp. 71-102.

Kozlov A.I., Vershubsky G. Secular trends in average height and age at menarche of ethnic Russians and Komi-Permyaks of the Permsky Krai, Russia. Anthropol. Anz., 2015, 72 (1), pp. 27-42. Mironov B. The Standard of Living and Revolutions in Russia, 1700-1917. London and New York, Routledge, Taylor \& Francis Group, 2012. 704 p.

Pallas P.S. Reise Durch Verschiedene Provinzen des Russischen Reichs. Sankt-Peterburg, Gedruckt bey der kayserlichen Academie der Wissenschaften, 1786. Theil 2, I. 368 p.

Shephard R.J., Rode A. The Health Consequences of "Modernization": Evidence from Circumpolar Peoples. Cambridge, Cambridge University Press, 1996. 306 p.

Sirelius U.T. Reise zu den Ostjaken. Helsinki, Suomalais-ugrilainen Seura, 1983. $350 \mathrm{p}$.

Sorkin J.D., Muller D.C., Andres R. Longitudinal change in height of men and women: Implications for interpretation of the Body Mass Index. Am. J. Epidemiol., 1999, 150 (9), pp. 969-977.

Strickland S.S. Ageing in non-Western populations. In: The Cambridge Encyclopedia of Human Growth and Development. Ed. by S.J. Ulijaszek, F.E. Johnston, M.A. Preece. Cambridge, Cambridge University Press, 1998, pp. 428-429.

Wigle D., Gilman A., McAllister K., Gibbons T. Analysis of Arctic Children and Youth Health Indicators. Future of Children and Youth of the Arctic Initiative, Report of the Health Programme, Canada, 2005. $111 \mathrm{p}$.

\section{Author's information}

Kozlov Andrey I., Ph.D., D.Sci., senior researcher, dr.kozlov@gmail.com;

Vershubsky Galina G., ggver@ya.ru;

Butovskaya Marina L., Ph.D., D.Sci., professor,

marina.butovskaya@gmail.com;.

Kozlova Maria A., Ph.D., associated professor,

makozlova@yandex.ru;

Fedenok Julia N., Ph.D., researcher, fedenok.julia@gmail.com. 


\section{Козлов А.И. ${ }^{1)}$, Вершубская Г.Г. ${ }^{1)}$, Бутовская М.Л., ${ }^{2,4)}$, Козлова М.А. ${ }^{4}$, Феденок Ю.Н. ${ }^{2)}$ \\ 1) МГУ имени МВЛомоносова, НИИ и Музей антропологии, 125009, ул. Моховая, д. 11, Москва, Россия \\ 2) Институт этнологии и антропологии РАН, 119334, Ленинский просп., 32a, Москва, Россия \\ 3) Российский государственный гуманитарный университет, 125993, Миусская пл., 6, Москва, Россия \\ 4) Национальный исследовательский университет - Высшая школа экономики, \\ СЕКУЛЯРНЫЕ ТРЕНДЫ ДЛИНЫ ТЕЛА И РАЗМЕРОВ ТАЗА ОБСКИХ УГРОВ (ХАНТОВ И МАНСИ)} 101990, ул. Мясницкая, 20, Москва, Россия

Введение. Цель исследования - рассмотрение долговременных изменений длины тела и ширины таза женщин коренного населения Севера Западной Сибири - северных хантов и сосьвенских манси.

Материал и обсуждение. Изменения с 1860-х по 1990-е годы прослежены по средним значениям признаков, определенных для когорт рождения, охватывающих десятилетние интервалы. Длина тела обских угров в когорте рождения с 1860-х по 1930-е значимо не менялась. В последующих поколениях вплоть до когорты рождения 1990-х длина тела увеличилась. Мужчины стали выше на 11,3 см, женщины - на 10,4 см (p<0,0001 в обоих случаях). Относительный (к длине тела когорты рождения 1930-х) прирост составил $+7,18 \%$ и $+7,06 \%$ для мужчин и женщин соответственно. $У$ женщин существенно изменились пропорции тела. Увеличение роста сопровождалось уменьшением ширины таза (d. cristarum) с 28,9 см в когорте рождения 1930-х до 26,8 см в когорте рождения 1970-х. В результате относительная ширина таза уменьшилась на 2,1\% (фрактор принадлежности к когорте значим, $p=0,0001)$.

Заключение. Длина тела обских угров изменялась неравномерно. Изменения соматических признаков следовали за социальными трансоормациями. Улучшение условий жизни в период индивидуального роста и развития влияло на дефинитивную длину тела. Таким образом, долговременные изменения соматических характеристик хантов и манси согласуются с гипотезой секулярных трендов как отражения «качества среды обитания».

Ключевые слова: долговременные изменения; рост; пропорции тела; d. cristarum; взрослые; коренное население Севера; Сибирь

\section{Библиография}

Давыдова Г.М. Антропология манси. М.: Ин-т этнографии АН СССР, 1989. 128 с.

Кабузан В.М. Народы России в XVIII веке. Численность и этнический состав. М.: Наука. 1990. 256 с.

Козлов А.И., Лисицын Д.В., Козлова М.А., Богоявленский Д.Д., Боринская С.А. и др. Кольские саамы в меняющемся мире. М.: Институт Наследия, ИЛ «АрктАн-С», 2008. 96 с.

Лукьянченко Т.В. Государственная политика и традиционная культура саамов: Проблемы возрождения // Расы и народы. Вып. 28. М.: Наука, 2002. С. 110-120.

Носилов К.Д. Антропологический очерк вогулов // Протокол заседаний Антропологического отделения Общества любителей естествознания, антропологии и этнографии с 4 декабря 1881 г. по 1886 год, 1886 . С. 528-539.

Пивнева Е.А. Манси: Популяционная структура, этнодемографрические процессы (XVIII-XX вв.). М.: ИЭА РАН. 1999. 306 с.
Руденко С. Антропологическое исследование инородцев Северо-Западной Сибири // Записки Имп. Акад. Наук. Сер. 8 по физ.-мат. отд. Петроград, 1914. Т. 33 (3). С. 1-125.

Соколова 3.П. Социальная организация хантов и манси в XVIIIXIX вв. Проблемы фрратрии и рода. М.: Наука. 1983. 324 с.

\section{Сведения об авторах}

Козлов Андрей Игоревич, д.б.н., старший научный сотрудник, dr.kozlov@gmail.com;

Вершубская Галина Григорьевна, ggver@ya.ru; Бутовская Марина Львовна, д.и.н., професссор, marina.butovskaya@gmail.com;

Козлова Мария Андреевна, к.и.н., доцент, makozlova@yandex.ru;

Феденок Юлия Николаевна, к.и.н., научный сотрудник, fedenok.julia@gmail.com. 